Angelina Raičković

Arheološki institut Beograd

Saša Redžić

Arheološki institut Beograd

Dragana Rogić

Arheološki institut Beograd

UDK 904:738.6(497.11)"01/02"

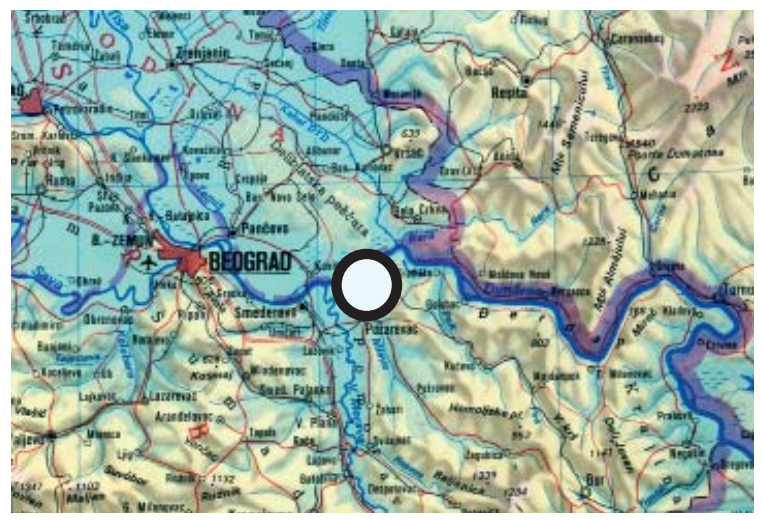

Viminacium, Stari Kostolac, Srbija

LAT $44^{\circ} 44^{\prime} 09^{\prime \prime}$ / LONG $21^{\circ} 12^{\prime} 42^{\prime \prime}$

\title{
TERAKOTE SA PROSTORA ZANATSKOG CENTRA VIMINACIJUM
}

\begin{abstract}
ABSTRAKT
Tema rada su terakote i kalupi za terakotu pronađeni u otpadnoj jami i sloju šuta u okviru istraženog dela Zanatskog centra na Viminacijumu. One su deo proizvodnog asortimana ovog zanatskog centra, a njihova brojnost skoncentrisana na jednom malom prostoru vezuje ih za određenu peć i otpadnu jaтu uz nju. Lokalni su proizvod i predstavljaju jeftiniju zamenu za razne figurice rađene u metalu ili mermeru.
\end{abstract}

KLJUČNE REČI: TERAKOTA, KALUPI ZA TERAKOTU, VIMINACIJUM, ZANATSKI CENTAR, OTPADNE JAME, KERAMIČKI PROIZVODI.

U toku istraživanja Zanatskog centra na Viminacijumu u prostoru nazvanom kanal za kišnu kanalizaciju otkriveno je nekoliko otpadnih jama. Sadržaj kojim su bile ispunjene tri otpadne jame činili su fragmenti keramičkih posuda, žižaka, opeka i terakota. Pronalazak kalupa za terakote i samih terakota vezan je na celom prostoru Zanatskog centra samo za otpadnu jamu br. 3 i jedan fragment terakote u sloju šuta u kvadratu XXXI (Plan br. I). Postojanje ovih otpadnih jama u neposrednoj blizini peći vezuje ih direktno za njih sa tim naglaskom da su peći uz koje vezujemo ove tri jame po svojoj funkciji opredeljene kao opekarske peći. Njihova konstrukcija i veličina, te fragmenti opeka, imbreksa i tegula nesumljivo na to ukazuju. Zanimljivo je da su velike opekarske peći mogle istovremeno da se koriste i za pečenje drugih keramičkih proizvoda kao što su posude, žišci ili terakote. ${ }^{1} \mathrm{U}$ prvi mah za očekivati je da se velike peći iskoriste za pečenje velikih posuda, međutim, pronađeni materijal kako u samim pećima, tako i u otpadnim jamama u njihovoj neposrednoj blizini nam daje upravo suprotnu sliku.

Uz ovu terakotu nađeno je i nekoliko fragmenata zdela, lonaca, krčaga i jedne amfore ( $\mathrm{T}$. III), zatim nekoliko žižaka, kalup za reljefne posude, pečat, bronzani, loše očuvani novčić, igla i koštana oplata (T. IV).

1. Za terakote se još koriste i izrazi glinene statuete, terakotna plastika, koroplastika i dr. 
Proizvodnja terakota je značajna jer su one zamenjivale skupocenije skulpture rađene od kamena ili bronze i samim tim bile dostupnije širem sloju stanovništva. Masovno su proizvođene. Ponekad su predstavljale skromne i neuspele imitacije nekih drugih dela rađenih u kamenu, metalu, mozaiku, na gemama ili žišcima, rađenim u drugim tehnikama, a ponekad su bile proizvod ličnog viđenja i umetničkih sklonosti majstora. Kroz proučavanje terakota mogu se pratiti promene u materijalnoj kulturi i razvitak tehnoloških karakteristika celokupne keramičke proizvodnje jer se tehnika izrade terakote menjala kroz vekove. ${ }^{1}$ Proizvodi od terakote imali su višestruku namenu. Mogli su se prinositi kao votivni darovi u hramovima i kućnim kapelicama, prilagati u grobove, a imali su i dekorativnu funkciju i bili poklanjani kao igračke ili kao poklon za uspomenu.

$\mathrm{Na}$ prostoru istraživanog dela Zanatskog centra otkriveno je ukupno 11 fragmenata terakote i kalupa. Podeljeni su u nekoliko grupa. Prvu grupu čine tri kalupa za izradu ženskih likova u en face položaju, drugu grupu čine maske, treću ukrasne pločice, četvrtu biste i petu igračke. Ovakva podela mora se shvatiti uslovno i napravljena je samo radi lakšeg grupisanja i opisivanja pronađenog materijala.

\section{KATALOG}

Sl. 1 Kalup za terakotu i otisak terakote, gornji deo ručno modelovanog mrko pečenog kalupa koji je služio za izradu ženske biste u en face položaju. Ženski lik je prikazan sa bujnom kosom razdeljenom po sredini glave koja pada u pramenovima sa strane lica i sa velom koji natkriva glavu. Oko vrata lika nazire se trag lančića ili ogrlice, a na grudima se naziru nabori haljine. Visina $6,3 \mathrm{~cm}$.

Sl. 2 Mrko pečeni kalup i otisak terakote ručno modelovan, predviđen za izradu ženske biste u en face položaju. Ne vidi se da li se radi o velu ili kosi koja pada na ramena. Nos je šematski izveden u obliku trougla i sa tek naznačenim očima i ustima.

1. Pejović 1995, 37.
Visina $5,7 \mathrm{~cm}$.

S1. 3 Mrko pečeni kalup za terakotu i otisak terakote, ručno modelovan, prikazuju en face ženski lik uokviren kratkim kovrdžama. Lepo izvedene kovrđe, naglašena deblja usta i mali nos, te bucmasti obrazi možda prikazuju i dete. Visina $6,7 \mathrm{~cm}$.

Sl. 4 Donji deo crveno pečene ploče rađene u kalupu. Na donjoj osnovi su prikazana tri lika (boja pečenja, Munsell: 7,5 YR 6/6). Posmatrani sa leva na desno: ženska glava sa dugačkom, po sredini razdeljenom kosom čiji su pramenovi na levoj strani glave naznačeni kosim urezima. Sa temena glave druge figure spuštaju se pramenovi kose koja je u slepoočnom delu privezana. Poslednja figura je najverovatnije muška, ima plitak pilos na glavi sa zadebljanim obodom. $\mathrm{Na}$ ovoj ploči se možda radi o prikazu mlađe ženske osobe, starije ženske osobe i muškarca. Predstavlja samo fragment veće ploče tako da nije poznata njena namena, a jedna od pretpostavki je da se radi o predstavama pozorišnih maski. Analogije za ovako izvedene likove nalazimo u Ptuju ${ }^{2}$ gde se isti likovi nalaze na pojedinačnim kalupima za terakotu bez bližeg objašnjenja o njihovoj simbolici. Dimenzije sačuvanog dela ploče su 10,7 x $5,7 \mathrm{~cm}$.

Sl. 5 Fragment crveno pečene terakote na kojoj je prikazana, možda, Venera. Očuvani su delovi koji se ne spajaju i veći deo sa šakom i nogama. Sa sigurnošću se može odrediti da je predstavljena ženska bista po naborima tkanine i po zaokrugljenom trbuhu preko kojeg je prebačena leva ruka koja pridržava tkaninu. Za Veneru smo se odlučili sledeći predstave Venere rađene u drugim tehnikama i materijalima. Dimenzije većeg sačuvanog dela su $11 \times 4 \mathrm{~cm}$.

Sl. 6 Fragment gornjeg dela tela sa očuvanom desnom rukom sa dugačkim rukavom koji je naznačen horizontalnim naborima i desno poprsje. Najverovatnije se radi o predstavi muške osobe, ali fragmentarna očuvanost ne dozvoljava detaljnije identifikaciju. Dimenzije sačuvanog dela 9 x $5 \mathrm{~cm}$.

S1. 7 Fragment maske od koje je očuvan gornji deo lica sa delom dijademe. Rađena je u kalupu.

2. Žižek 2004, 124. 
Dimenzije 14 x $12 \mathrm{~cm}$. Radi se o ženskom liku na kome je kosa prikazana sitnim urezima.

S1. 8 Fragment nogu i dela draperije na cilindričnom šupljem postolju. Prečnik postolja je $9 \mathrm{~cm}$. Mogu se razaznati noge konja i deo dvokolica. Radi se najverovatnije o figurici koja je rađena po uzoru na neku rađenu u bronzi, a analogije za to nalazimo u sitnoj bronzi Singidunuma. Dimenzije sačuvanog dela $7 \times 5 \mathrm{~cm}$.

S1. 9 Dve polovine kalupa, gornjeg i donjeg dela. Očuvan je deo nogu i pravougaono postolje. Po zaobljenosti tela može se zaključiti da se radi o nagoj ženskoj osobi. Kalup je sačuvan od dela leđa pa do postolja sa zadnje strane, a sa prednje od struka do dna postolja. Dimenzije većeg sačuvanog dela $10,5 \times 6 \mathrm{~cm}$.

S1. 10 Fragment crveno pečene maske. Očuvan je deo arkade i deo sa kosom. I u ovom slučaju najverovatnije se radi o ženskom liku veoma sličnom liku iz kalupa br. 1, s tim da ova maska ima svog dvojnika i u bronzanoj aplikaciji pronađenoj na istom mestu. Bogati nabori kose podeljene po sredini temena prekriva linijski prikazana dijadema. Dimenzija 16,5 x 18,5 cm.

S1. 11 Crveno pečeni točak za dečija kolica sa perforacijom na sredini i sa paorcima prečnika 6 $\mathrm{cm}$. Ovakav točkić je najverovatnije deo igračke od dečijih kolica kakva su nalažena i na drugim lokacijama na Viminacijumu. Točkovi su izrađeni od pečene gline, a ostali delovi od drveta koje se nije sačuvalo. Isti točkići mogu biti i deo terakote u obliku konjića. ${ }^{3}$ Prečnik točkića je $6 \mathrm{~cm}$.

Pošto su najveći broj kalupa za terakotu i terakota iz Zanatskog centra nađeni na manjem prostoru koji je bio zatvoren slojem šuta, a u okviru otpadne jame, potrebno je prikazati i skrenuti pažnju i na ostali keramički materijal pronađen u toj zatvorenoj celini. U prilogu je data tabela sa grafikonima oblika posuda iz ove celine. ${ }^{4}$

Oblici posuda koji se javljaju u ovoj otpadnoj jami rađeni su od srednje prečišćene gline crvene

3. Premk 1994, Fig. 8.

4. Oblici posuda obrađeni su detaljnije u magistarskoj tezi A. Raičković koja je u rukopisu. boje pečenja i spoljne površine neobrađene ili bojene tonovima crvene boje. To su oblici koji su korišćeni u svakodnevnom životu za pripremanje, služenje i konzumiranje hrane i pića. Hronološki ovi oblici nisu preterano osetljivi i njihovo datovanje u okviru Zanatskog centra je od druge polovine II veka kroz ceo III vek.

Kalupi za figurice, polufigurice, aplikacije i ostalo, rađeni su vrlo rustično, od iste gline kao i posude i time pokazuju da su ih proizvodili ovdašnji majstori. I na drugim lokacijama na Viminacijumu javljaju se u broju koji može da opravda pretpostavku o postojanju radionice za njihovu proizvodnju u Zanatskom centru. Nedostaju analogije koje nije lako pronaći jer su terakote proizvođene po ukusu lokalnih majstora i kao takve analogije im se mogu naći samo u sličnim predmetima rađenim u drugim, uglavnom skupljim i ređim materijalima.

Analogije za način izrade i motive na terakotama možemo naći u radionicama sledećih rimskih centara: Poetovio, Siscia, Neviodunum, Mursa, Teutoburgium, Sirmium i Singidunum.

\section{RESUME \\ Terracottas From the Viminacium Production Center}

The terracottas found in the rubbish pit nr. 3, as well as a single example found in the debris layer, represent a part of a broad repertoire of the Viminacium production center. According to small finds, as well as to pottery and brick kilns, this manufacturing center can be dated from the middle of $2^{\text {nd }}$ century throughout the whole $3^{\text {rd }}$ century. This is also the period of production of such terracottas and their moulds. Rustic appearance points out to local craftsmen. The clay of the same quality and colour confirms this hypothesis and shows that this manufacturing center was the place of their production. Further on, this is confirmed by a great number of over 200 terracottas found at other locations at Viminacium.

Translated by M. Tapavički-Ilić 


\section{BIBLIOGRAFIJA}

\section{Pejović 1995}

Z. Pejović, Terakote iz zbirke muzeja Srema, Zbornik muzeja Srema 1, Sremska Mitrovica 1995, 37 -62 .

\section{Premk 1994}

A. Premk, Terra-Cotta Animal Figurines from Viminacium, Starinar XLV-XLVI, Beograd 1994/95, $143-155$.

\section{Raičković 2005}

A. Raičković, Keramičke posude Zanatskog centra iz Viminacijuma, magistarska teza u rukopisu, Beograd 2005.

\section{Veličković 1957}

M. Veličković, Katalog grčkih i rimskih terakota, Beograd 1957.

\section{Žižek 2004}

I. Žižek, Katalog predmeta, Rimljani: steklo, glina, kamen, Katalog za izložbu, Celje 2004, 124 - 143. 
P. I

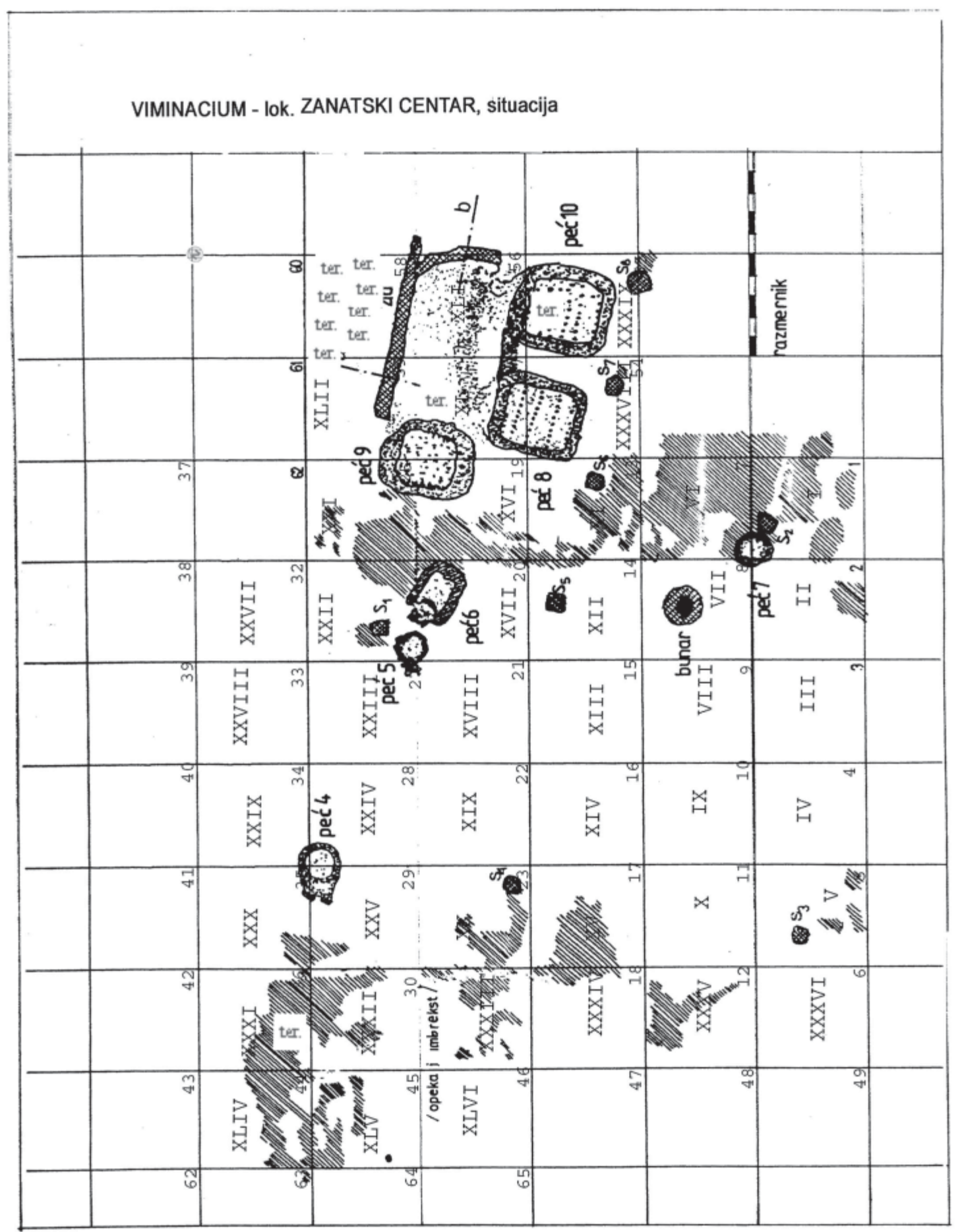

Mesto nalaza terakota u Zanatskom centru 

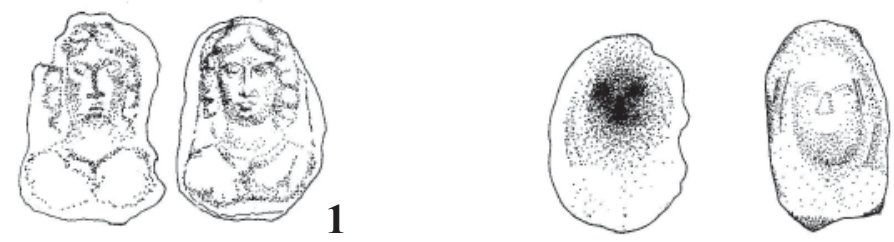

2
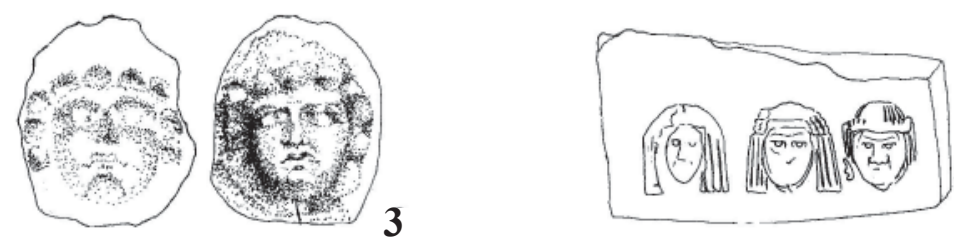

4
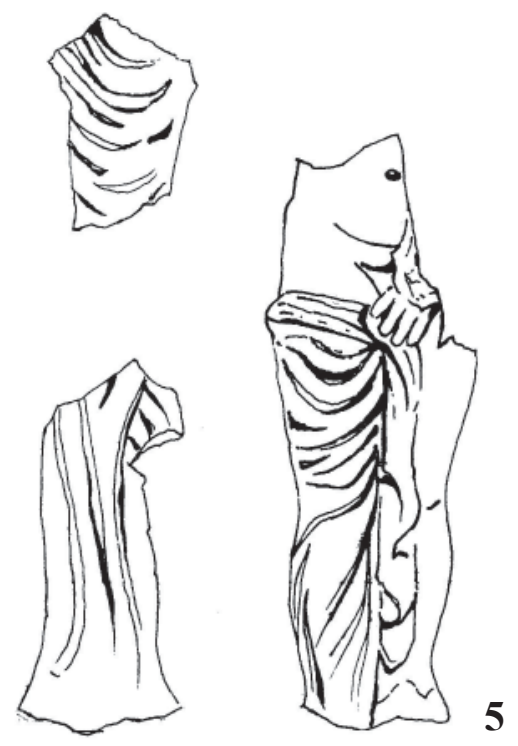

R (2:3) 


\section{T. II}
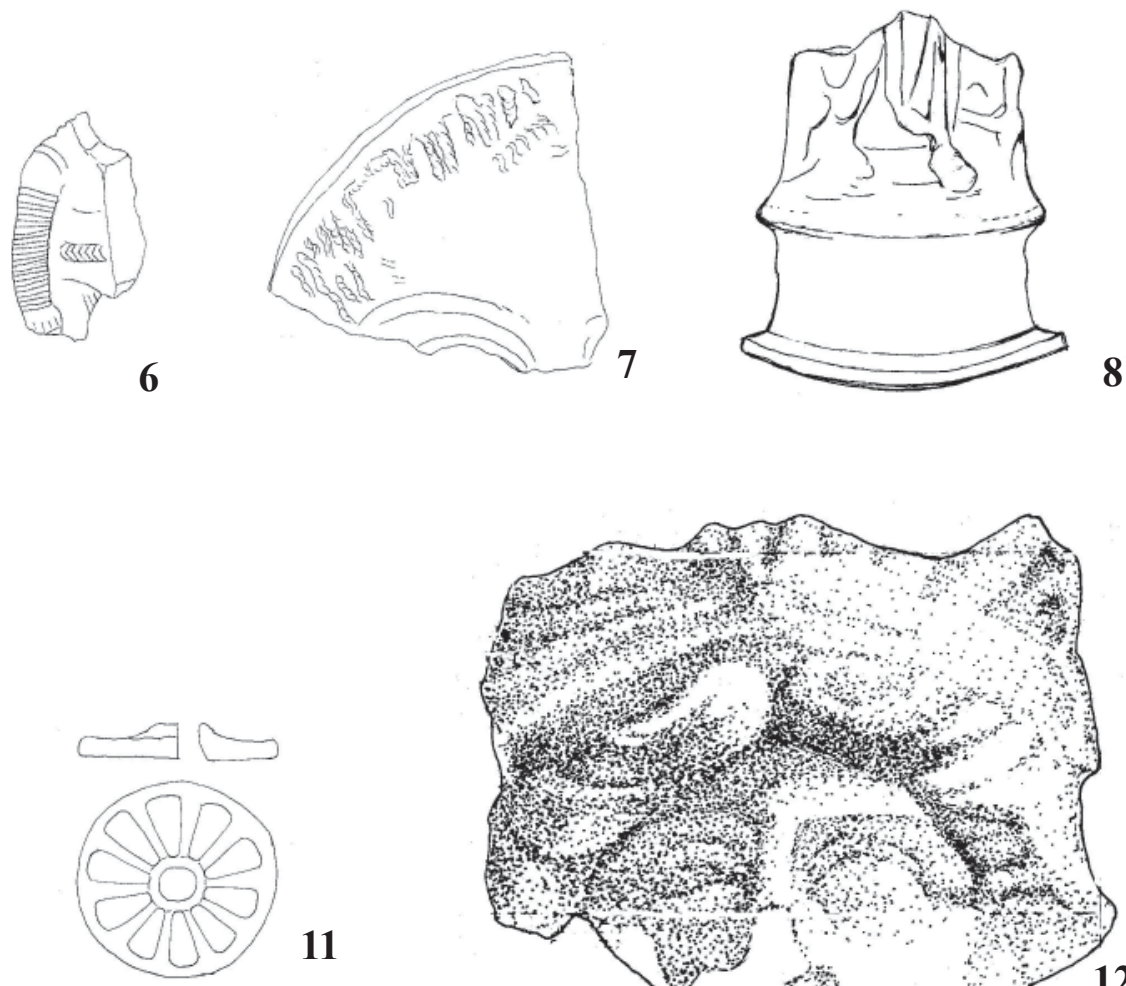

11
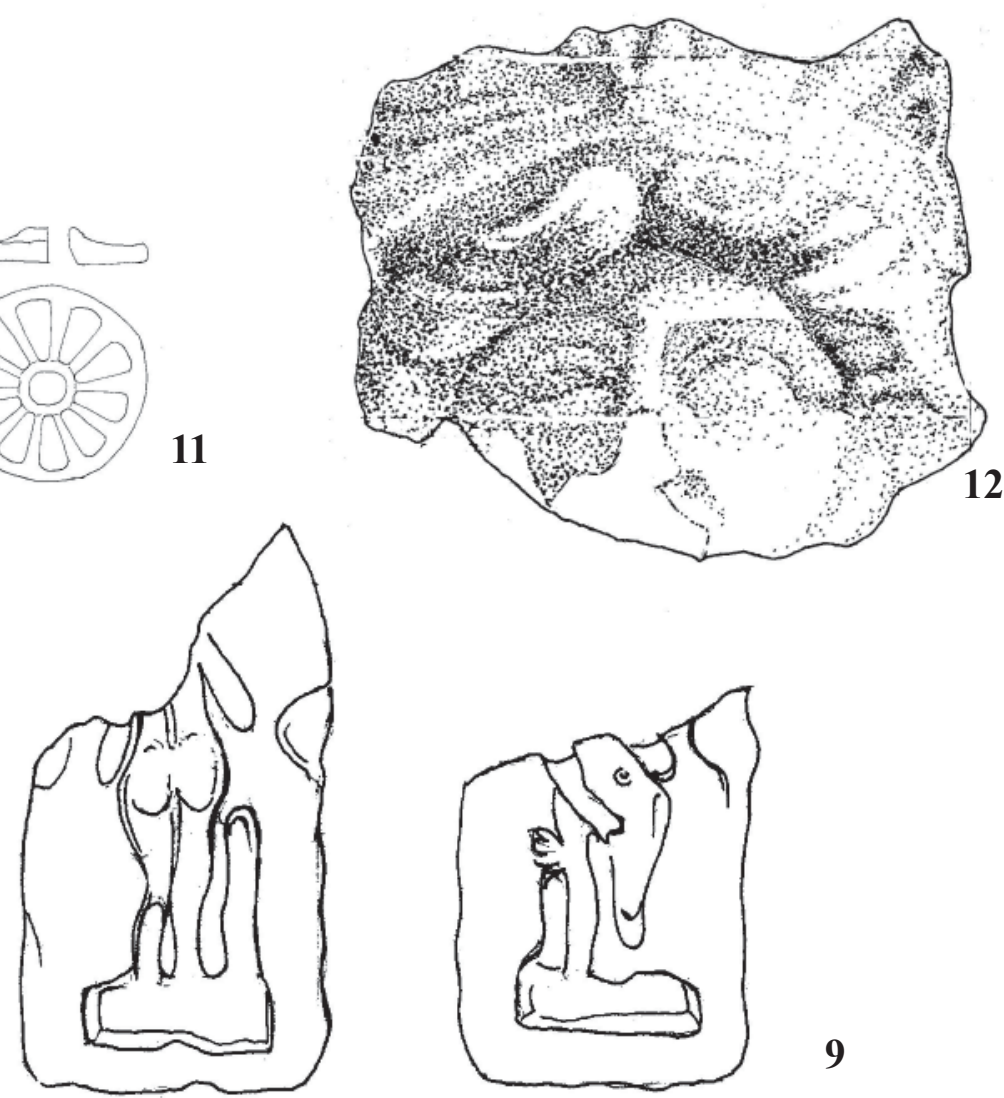

9

$\mathrm{R}(2: 3)$ 
T. III
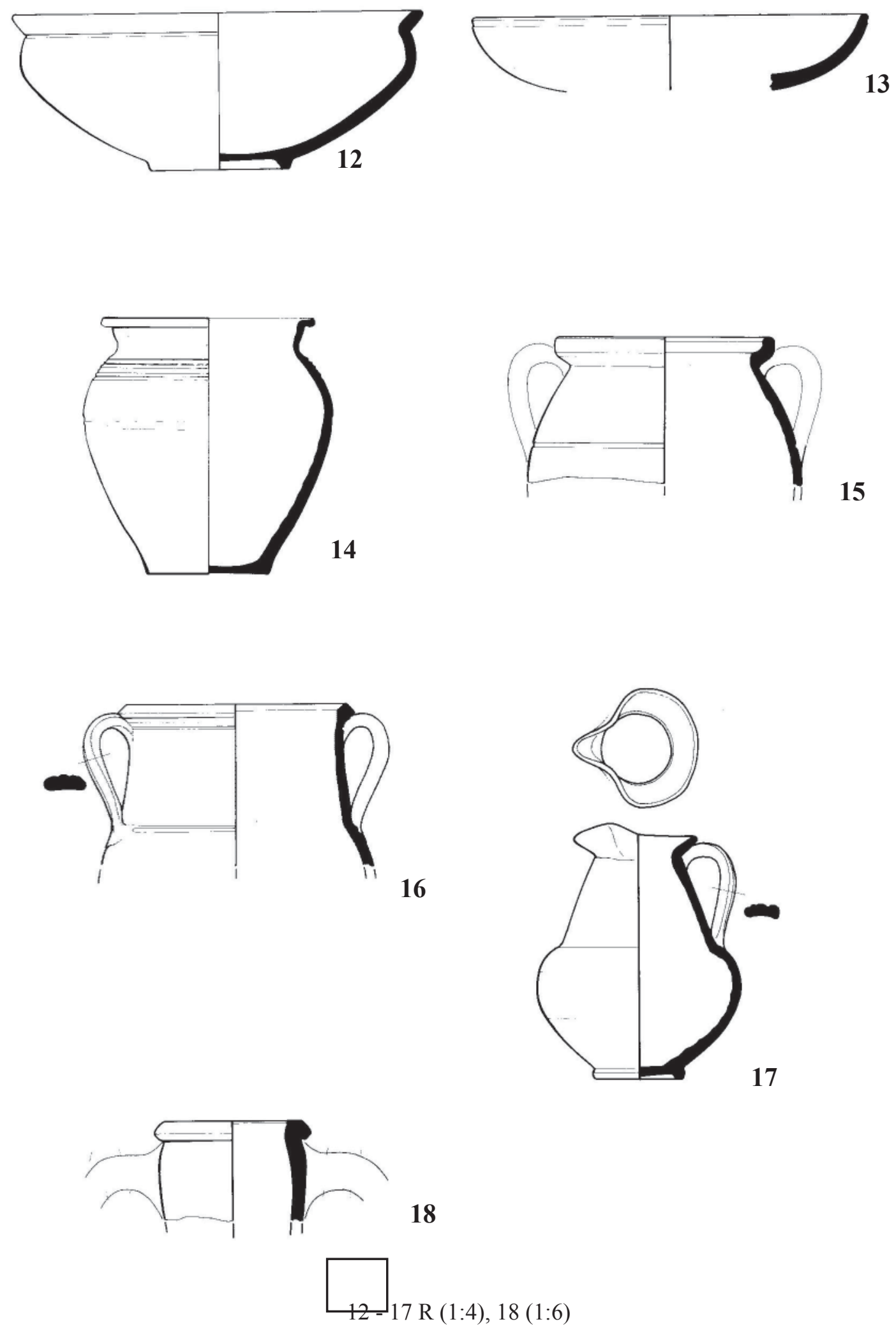


\section{T. IV}
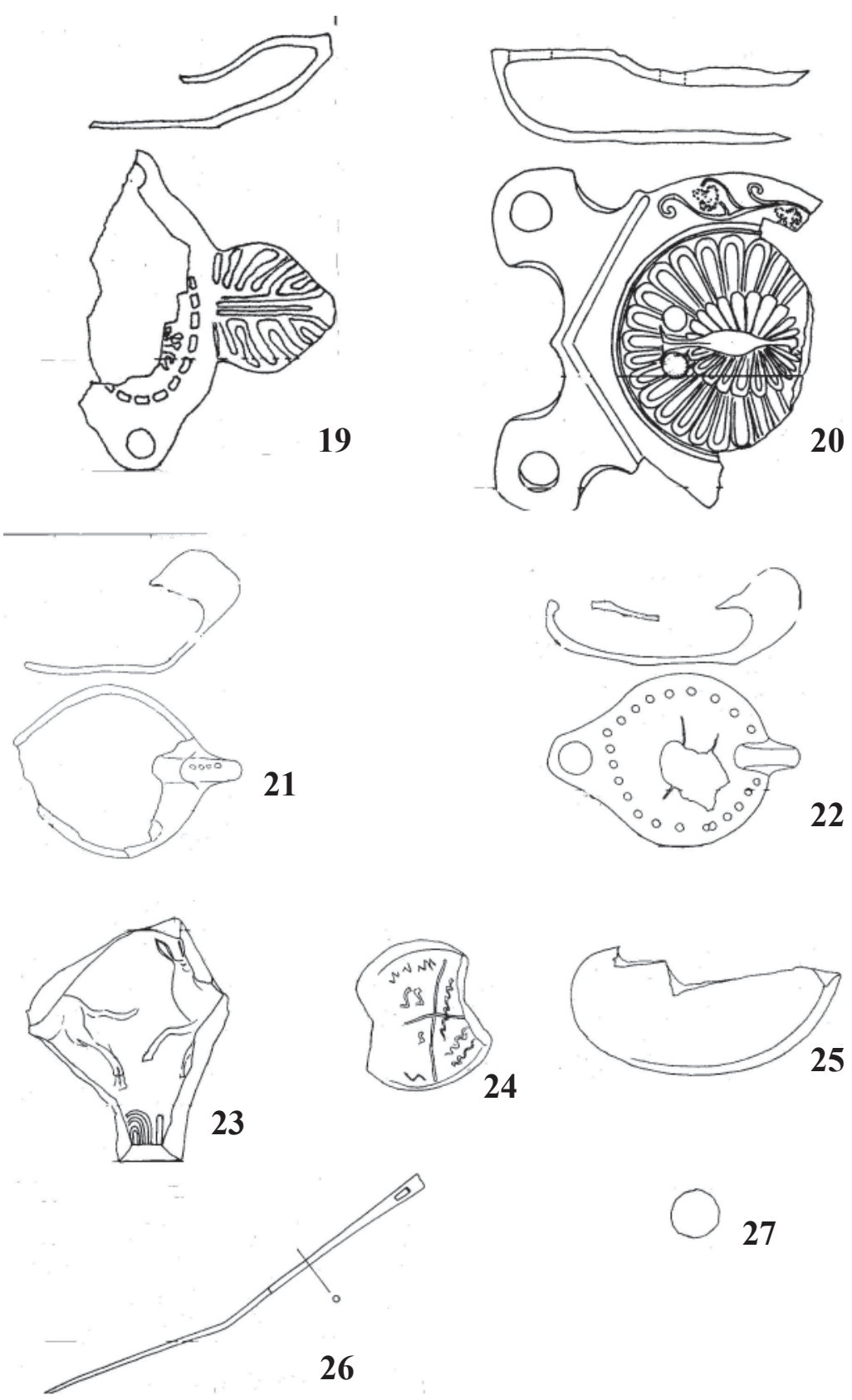

27

$\mathrm{R}(2: 3)$ 